\title{
FIELD STATION LOCATIONS AND MAGNETIC SUSCEPTIBILITY DATA COLLECTED IN 2021 FOR THE TAYLOR MOUNTAIN PROJECT, TANACROSS AND EAGLE QUADRANGLES, ALASKA
}

Michelle M. Gavel, Alicja Wypych, Travis J. Naibert, Dylan F. Avirett, Michael L. Barrera, Angie K. Hubbard, Rainer J. Newberry, Sean P. Regan, Evan Twelker, Alec D. Wildland, and W. Chris Wyatt

\section{Raw Data File 2022-2}

2022

STATE OF ALASKA

DEPARTMENT OF NATURAL RESOURCES

DIVISION OF GEOLOGICAL \& GEOPHYSICAL SURVEYS
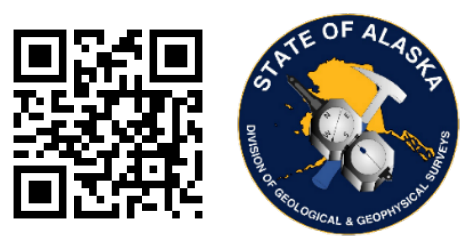
STATE OF ALASKA

Mike Dunleavy, Governor

\section{DEPARTMENT OF NATURAL RESOURCES}

Corri A. Feige, Commissioner

\section{DIVISION OF GEOLOGICAL \& GEOPHYSICAL SURVEYS}

Steve Masterman, State Geologist \& Director

Publications produced by the Division of Geological \& Geophysical Surveys are available to download from the DGGS website (dggs.alaska.gov). Publications on hard-copy or digital media can be examined or purchased in the Fairbanks office:

\section{Alaska Division of Geological \& Geophysical Surveys (DGGS)}

3354 College Road | Fairbanks, Alaska 99709-3707

Phone: 907.451.5010 | Fax 907.451.5050

dggspubs@alaska.gov $\mid$ dggs.alaska.gov

DGGS publications are also available at:

Alaska State Library, Historical

Collections \& Talking Book Center

395 Whittier Street

Juneau, Alaska 99801

Alaska Resource Library and

Information Services (ARLIS)

3150 C Street, Suite 100

Anchorage, Alaska 99503

\section{Suggested citation:}

Gavel, M.M., Wypych, Alicja, Naibert, T.J., Avirett, D.F., Barrera, M.L., Hubbard, A.K., Newberry, R.J., Regan, S.P., Twelker, Evan, Wildland, A.D., and Wyatt, W.C., 2022, Field station locations and magnetic susceptibility data collected in 2021 for the Taylor Mountain project, Tanacross and Eagle quadrangles, Alaska: Alaska Division of Geological \& Geophysical Surveys Raw Data File 2022-2, 2 p. https://doi.org/10.14509/30837
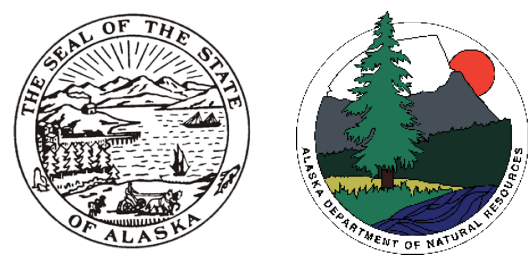


\section{FIELD STATION LOCATIONS AND MAGNETIC SUSCEPTIBILITY DATA COLLECTED IN 2021 FOR THE TAYLOR MOUNTAIN PROJECT, TANACROSS AND EAGLE QUADRANGLES, ALASKA}

Michelle M. Gavel ${ }^{1}$, Alicja Wypych'1 ${ }^{1}$ Travis J. Naibert', Dylan F. Avirett' ${ }^{1}$, Michael L. Barrera', Angie K. Hubbard', Rainer J. Newberry', Sean P. Regan'², Evan Twelker', Alec D. Wildland', and W. Chris Wyatt'

\section{INTRODUCTION}

During the 2021 field season, geologists from the Alaska Division of Geological \& Geophysical Surveys (DGGS) conducted 1:100,000-scale bedrock geologic mapping of $2600 \mathrm{mi}^{2}\left(\sim 6900 \mathrm{~km}^{2}\right)$ within the Tanacross and Eagle quadrangles. The field area for the Taylor Mountain project is within a 50-mile radius of Chicken, Alaska. The project area is of current and historic interest for potential mineral resource development, including quartz vein Au mineralization, placer Au deposits, granite-hosted tin mineralization, and intrusion-related $\mathrm{Cu}$-Au deposits. Prospects in the area include Tweeden, Liliwig, and others. Much of the field area was mapped at 1:250,000 scale by the USGS in the 1960s (Foster, 1970; 1972). This project aims to produce more accurate and modern geologic maps and supporting datasets that will promote mineral resource exploration in eastern Interior Alaska.

This report provides locations, field descriptions of rocks, and magnetic susceptibility measurements from rock outcrop and/or hand samples throughout each map area. The data associated with this report are available in digital format as a comma-separated value (CSV) file. All files can be downloaded from the DGGS website: https://doi.org/10.14509/30837.

\section{DOCUMENTATION OF METHODS}

Location data for field stations were collected using GPS-enabled tablets or smartphones running the ESRI Field Maps App. Data were merged into an ArcGIS geodatabase. The devices have a reported error between 10-12 m. Latitude and longitude are reported in the WGS84 datum.

Field rock descriptions are composed of observations and interpretations made by project geologists in the field or in the field office. Field observations and rock descriptions in this data file have not been reviewed for technical content and should be considered preliminary. As the project commences, further observations, geochemical data, microscopic investigation, or other information may provide additional insights into sample and station lithology or features. Revised descriptions may become available in the future through new publications, DGGS web services, or division databases.

Magnetic susceptibility measurements were collected using Terraplus KT-10 model handheld magnetic susceptibility meters. The KT-10 meters have a maximum sensitivity of $1 \times 10^{-6} \mathrm{SI}$ units on smooth surfaces and a measurable susceptibility range between $0.001 \times 10^{-3}$ and $1999.99 \times 10^{-3} \mathrm{SI}$. The values reported

\footnotetext{
${ }^{1}$ Alaska Division of Geological \& Geophysical Surveys, 3354 College Road, Fairbanks, Alaska 99709-3707

${ }^{2}$ Department of Geology \& Geophysics, University of Alaska, P.O. Box 755780, Fairbanks, AK 99775-5780
} 
here are for individual measurements performed on representative surfaces of the sampled rock outcrop and/or hand samples. Up to twelve susceptibility readings were recorded at each field station. Efforts were made to avoid atmospheric effects by measuring multiple sides of outcrops and/or hand samples whenever possible. Magnetic susceptibility was not measured at a minority of field stations because hand samples were intensely weathered or not large enough to cover the coil of the KT-10 meter for accurate measurement. These stations are presented with zero measurements for completeness.

\section{ACKNOWLEDGEMENTS}

The DGGS Taylor Mountain Project was funded by State of Alaska General Funds and the U.S. Geological Survey under Cooperative Agreement Number G21AC10326.

Disclaimer: The views and conclusions contained in this document are those of the authors and should not be interpreted as representing the opinions or policies of the U.S. Geological Survey. Mention of trade names or commercial products does not constitute their endorsement by the U.S. Geological Survey.

\section{REFERENCES}

Foster, H.L., 1970, Reconnaissance geologic map of the Tanacross Quadrangle, Alaska: U.S. Geological Survey Miscellaneous Geologic Investigations Map 593, 1 sheet, scale 1:250,000.

Foster, H.L., comp., 1972, Preliminary geologic map of the Eagle Quadrangle, Alaska: U.S. Geological Survey Miscellaneous Field Studies Map 358, 1 sheet, scale 1:250,000. 